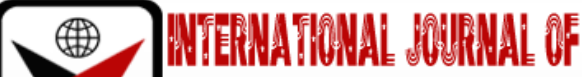

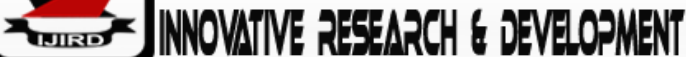

ISSN 2278-0211 (Online)

\section{The Impact of In-Service Training on Employee Performance in the Uganda Public Service: A Case of Civil Service College Uganda Alumni}

\begin{tabular}{|c|}
\hline Nasinyama Moses Makoha \\
Principal Research Officer, Ministry of Public Service, \\
Civil Service College Uganda, Uganda \\
Savia Nankya Mugwanya \\
Commissioner, Ministry of Public Service, \\
Civil Service College Uganda, Uganda \\
Joreme Ojulun \\
Principal Human Resources Officer, Ministry of Public Service, \\
Civil Service College Uganda, Uganda \\
Kenneth Maloba \\
Information Technology Officer, Ministry of Public Service, \\
Civil Service College Uganda, Uganda
\end{tabular}

\begin{abstract}
:
This study assessed the impact of in-service training programmes on employee performance in the Uganda Public Service, using Civil Service College Uganda Alumni as a case study. The study employed a cross sectional research design. The instrument was emailed for self-administration to a randomly selected population of 159 respondents, with 91 questionnaires filled and returned making an overall response rate of 57\% as this is a COVID-19 period where the country is still under Lockdown. Data generated were analyzed to generate descriptive statistics such as tables and graphs while the hypothesis was tested using a Multiple Regression Analysis at 0.05 level of significance. The findings showed that Civil Service College Uganda's various in-service training programmes were pertinent to the transformation and development of public servants in Uganda's Ministries, Department and Agencies (MDAs) and Local Governments (LGs) for improved public service delivery. Findings further revealed that in-service training programmes does have significant affect employee (Alumni) performance ( $F=32.390 ; p>0.05)$ as the significance value of 0.001 was less than the probability value of 0.05. The independent variable (in-house training programmes measured using induction (IND), Team building (TB), Strategic Leadership (SL), Impact Assessment (IA), Performance Enhancement (PE) and Voluntary Retirement (VR), statistically significantly predicted the dependent variable (employee performance), $\mathrm{F}(6,94)=32.390, \mathrm{p}<.005, \mathrm{R}^{2}=.577$ and all the six variables added, were statistically significantly to the prediction, $\mathrm{p}<.05$. The study therefore recommended that the Uganda government through her Ministry of Public Service-Civil Service College Uganda undertakes training needs assessment for different cadres (public employees) before administering in-service training, that in-service training opportunities lead to individuals' success and probably to institutional goal achievement and that institutional managements should allow employees some degree of autonomy in the use of their ideas to ensure they contribute positively to organization effectiveness and performance.
\end{abstract}

Keywords: In-service training programmes, employee (Alumni) performance, Civil Service College Uganda, Ministry of Public Service, Uganda

\section{Introduction}

The Education and training systems have a key role to play in ensuring that opportunities are provided for all individuals to develop their skills continually in a lifelong learning perspective, enabling them to adapt to rapidly changing labour market requirements and conditions (ETF-Cedefop-ILO, 2016). Training and labour market policy makers decide on the configuration of education and training systems, employment policies and investments. Training institutions decide on the type and content of the training courses to be delivered. Individuals and their families decide on their own education and training while employers take decisions on how to enhance the skills of their employees/ employees (ibid). Throughout the world, different countries are trying to create closer synergies between the needs and purposes of their education training systems, the local and regional labour markets, and their national economies. Aroge (2012) asserts that in Nigeria, there are various federal and state training centers all over the country. The private sectors also established 
their own training centers and schools while many others depend on private consultants and university organized training programmes and seminars as well as executive development and general management courses run by the Nigeria Institutes of Management (NIM) and that of Institute of Personnel Management (IPM). It is pertinent to note that there must be continuous reviews of manpower training to ensure that there is effectiveness throughout the organization so as to enable the organization achieve its objectives. It is also believed that a vast majority of new employees have not been prepared to perform the job they may encounter in their organizations irrespective of the technical or professional education they received.

Unwin (2003) observe that largely as a result of an international consensus which, though contested, argues that people and organizations need to embrace new skills and knowledge at regular periods in order to meet the challenges of a much more dynamic and unstable economic climate. In an environment where there is lack of a systematic and accurate examination of employment outcomes of formal and informal training graduates/ employees such as is the case in Uganda, it is difficult to establish any synergy between the economy and labour markets outcomes. In such cases, tracer studies could be used as a means of maintaining curriculum/ training relevance and providing targeted benefits to graduates/employees to enhance performance at the work place (ibid).

The Uganda Public Service continues to undertake the needed reforms to make a meaningful contribution towards the transformation of the country (MoPS, 2020). These reforms show a paradigm shift that encompasses not only the structures and systems but also the values, attitudes and mindset of public service employees. In this regard, the Civil Service College Uganda (CSCU), a department in the Ministry of Public Service as a centre of excellence in public service development is mandated to build, a department under the Ministry of Public Service is mandated to build the capacities of Public Service Institutions and human resources for improved performance in public service delivery. The College continuously upgrade and refresh the skills, knowledge and attitudes of public servants, including enhancing their leadership capacity to effectively respond to current and emerging local and global challenges. It is against this back ground that this study sought to the assess the impact of In-Service Training on Employee (Alumni) Performance in the Uganda Public Service, using Civil Service College Uganda Alumni as a case study.

\section{The Problem Statement}

Appiah (2010) argues that in-service training has been demonstrated to produce performance change through development of employee knowledge, skills, capability, proficiency and behavior. Ebru(2015) analyzing the In-Service Training of English Language Teachers at Elementary Schools in Turkey, concluded that, the in-service training has significant impact in the field of knowledge acquisition, aptitudes, attitudes and employment behavior. Emojong (2004) in a study on the effect of in-service training on Uganda Revenue Authority employees, established that the training was beneficial to the staff at URA at different lengths. Therefore, training should be considered as one of the necessary managing procedures in quality management that plays a vital role in organizational development and in development of human resources. Civil Service College Uganda on behalf of Government of Uganda is mandated to undertake in-service training classes, however, these training opportunities involves huge sum of financial support; thus, managers need to be sure of productivity of such opportunities of their staff trained so as to avoid uncertainties. Therefore, making benefit of in-service training classes for employees and managers in Ministries, Department and Agencies (MDAs) and Local Governments (LGs) becomes a priority. This paper assessed the impact of in-Service Training on Employee Performance in the Uganda Public Service, using Civil Service College Uganda Alumni as a case study

\section{Objectives of the Study}

The study was guided by the following objectives:

- To identify the in-house training programmes undertaken by public employees (alumni) at CSCU.

- To examine how in-house training programmes affect public employees (Alumni) performance

- To capture suggestions on how the College can support the public employees (Alumni) to use the learning for tangible performance improvement and continued learning.

\section{Hypothesis of the Study}

- H0: In-House Training programmes have no significant effect on public employees (Alumni) performance

\section{Empirical Review}

Ezigbo (2003) observe that Training and development programmes of an organization help to improve a worker's skill and technical competence by integrating a worker in the organization and integrate the diverse departments of an organization as a whole. No organization or federal parastatal has a choice of whether to twin their employees or not, the only choice there is that of the method to use. Training helps implement employees' plans by improving the productivity of people already employed in the firm. In short, training makes better use of existing employee talent. William, Rothwell and Kazanas (2004) argue that training contributes to the realization of strategic business plans in two ways; first, it furnishes people involved in formulating plans with skills necessary to do it. Second, it provides new knowledge and skills to employees out each organizational level, so they can go about their jobs in ways leading to the realization of long-term plans. Training and development are important to employee in terms of better security and greater opportunity for advancement within and outside the organization

Lahsaeezadeh (2005) in his study entitles 'In-service training dimensions: concepts' which was accomplished over 89 employees of welfare organisation in Bushehr province. The result was that the certain organizations which held inservice training classes for employees displayed higher levels of productivity while they enjoyed better function rates. 
Mirsepasi (2010) in a paper entitled 'Productivity and productivity evaluation principles' concluded that optimal use of in-service training classes caused an improvement in human resources function in work place, arguing further that, if the necessary trainings are presented to employees, they will display more favourable administrative activities; thus, an optimal evolution in organization and increased rate of productivity among human resources are observed.

Grinyer and Singleton (2000)asserts that the most frequently used techniques in employees' development in acquiring job skill, attitude and efficiency, is on-the-job training, arguing further that trainee subordinate in acquiring job skill, uses the machinery and materials which they will use when the format training is completed and that in practices, onthe-job training varies in formal organizations from simple assigned the new employee to an experienced worker to be shown the job, to a formal arrangement with instructors assigned to grade and evaluate the training efforts of trainees. Reyans (1963) describes the training approach as his 'major positive performance of task'. In his analysis, he asserts that when for example in a hospital one brings together a senior matron, Doctor and a senior Administrator into a project team to look into a particular issue which they felt was important, one would observe that there will be a significant accomplishment of the project tasks and the administrator will learn more from the team on hospital activities.

\section{Methods and Materials}

The study adopted a cross sectional study design incorporating both quantitative and qualitative methods to data collection. The population in this study constituted public employees (alumni) in Ugandan Public Service, who had trained with CSCU in the last three years (2018-2020). Yamane (1967) sample size formula was used for determining sample size of the study.

$$
n=\frac{N}{1+N(e)^{2}}
$$

Where,

$\mathrm{n}$ is the sample size required

$\mathrm{N}$ is the total population size (263 alumni) in the last three years (2018-2020),

e is the error or confidence level (5\%) for the conventional confidence level of $95 \%$ used to ensure a more accurate result from the sample.

Based on the above formula, the sample size was calculated as follows:

$$
n=\frac{263}{1+263(0.05)^{2}}=\frac{263}{1+263 * 0.0025}=\frac{263}{1+0.6575}=\frac{263}{1.6575}=159 \text { Re spondents }
$$

Therefore, the study sample was 159 public employees (Alumni) from twelve Ministries, Departments and Agencies (MDAs) and Local Governments (LGs) using simple random sampling technique because it allows items in population fair chances for inclusion in study frame. The questionnaire was developed and pre-tested for validity and reliability as recommended by Joppe (2000). Both open and Closed ended type of questionnaire was used for the study. One hundred and fifty-nine (159) questionnaires were emailed to respondents as this was Covid-19 pandemic and lockdown period in Uganda, ninety-one (91) questionnaires were returned. Descriptive statistics such as frequency tables, mean and standard deviation were used to analyze the research questions while Analysis of Variance (ANOVA) and regression analysis were used to analyze the relationship between types of training programmes and employee performance variables.

\section{Findings}

Results from Table 1 below show respondents' response rate across entities that trained with the CSCU for the period 2018 - 2020. A total of 159 respondents were targeted and emailed the questionnaires for self-administration. Of the 159 respondents targeted for this study, 91 actually responded and participated, overall returning $57 \%$ response rate.Visser et al. (1996) have shown that some studies with low response rates, even as low as $20 \%$, are able to yield more accurate results than studies with response rates of $60 \%$ to $70 \%$. Holbrook et al., (2007) concluded that studies with response rates ranging from $5 \%$ to $54 \%$, were often only marginally less accurate than those with much higher described response rates. Schaefer and Dillman (1998) observed that in a completed study comparing differing methods of administration, response rates close to $60 \%$ were achieved by multimode contacts. This mixed-mode approach, combining both mailed and e-mailed survey instruments with an Internet-based response mechanism, also is an approach to help reduce the problem of coverage error in administration of surveys. Therefore, the study response rate of $57 \%$ make the study findings reliable and valid which was over and above the $54 \%$ response rate as recommended by Holbrook et al., (2007) and Schaefer and Dillman (1998). 


\begin{tabular}{|c|c|c|c|c|}
\hline $\begin{array}{c}\text { Data Collection } \\
\text { Method }\end{array}$ & Entity & $\begin{array}{c}\text { Targeted } \\
\text { Respondents }\end{array}$ & $\begin{array}{c}\text { Actual } \\
\text { Response }\end{array}$ & Percent \\
\hline \multirow{13}{*}{$\begin{array}{c}\text { Survey } \\
\text { Questionnaire }\end{array}$} & Ministry of Public Service & 19 & 13 & $68 \%$ \\
\hline & $\begin{array}{l}\text { Ministry of Works and } \\
\text { Transport }\end{array}$ & 18 & 8 & $44 \%$ \\
\hline & Ministry of Local Government & 23 & 7 & $30 \%$ \\
\hline & $\begin{array}{c}\text { Office of the President-Cabinet } \\
\text { Secretariat }\end{array}$ & 7 & 5 & $71 \%$ \\
\hline & $\begin{array}{l}\text { Ministry of Finance, Planning \& } \\
\text { Econ Development }\end{array}$ & 13 & 8 & $62 \%$ \\
\hline & Jinja District Local Government & 12 & 9 & 755 \\
\hline & $\begin{array}{l}\text { Ministry of Agriculture, Animal } \\
\text { Industry \& Fisheries }\end{array}$ & 11 & 9 & $82 \%$ \\
\hline & State House & 7 & 6 & $86 \%$ \\
\hline & $\begin{array}{l}\text { Uganda Registration Service } \\
\text { Bureau }\end{array}$ & 13 & 5 & $38 \%$ \\
\hline & Office of the Auditor General & 10 & 8 & $80 \%$ \\
\hline & $\begin{array}{c}\text { Ministry of Defense and Veteran } \\
\text { Affairs }\end{array}$ & 15 & 7 & $47 \%$ \\
\hline & $\begin{array}{l}\text { National Agricultural Research } \\
\text { Organization }\end{array}$ & 11 & 6 & $55 \%$ \\
\hline & Total & 159 & 91 & $57 \%$ \\
\hline
\end{tabular}

Table 1: Response rate

Source: Survey Data (2021)

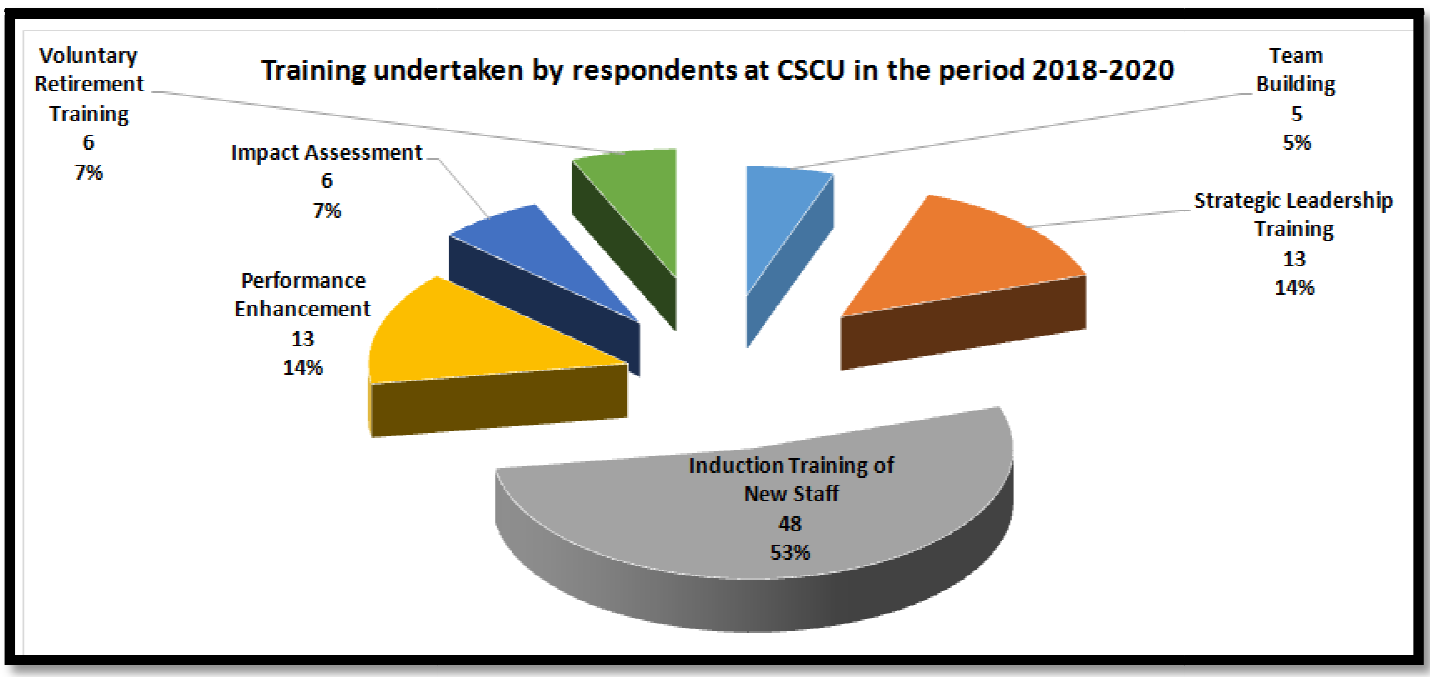

Figure 1: In-Service Training Carried Out During the Period 2018-2020 Source: Survey Data (2021)

Results from Figure 1 above shows the different in-house trainings undertaken by the respondents at CSCU for the period 2018-2020. Majority 53\% (48) of the respondents had been inducted as new staff joining the public service, 14\% (13) of the respondents had either trained in performance enhancement or strategic leadership, 7\% (6) of the respondent had trained either in voluntary retirement or impact assessment while 5\% (5) of the respondents had trained in team building. The implication from the study is that public institutions releasing the need to transform and improve public service delivery, are now acknowledging the value to train their employee to ensure higher levels of productivity while they enjoyed better functioning rates as argued by Lahsaeezadeh (2005) and Mirsepasi (2010) and this also alludes to the core mandate for the establishment of CSCU as a centre of excellence for public service transformation in Uganda.

- Ho: In-House Training programmes have no significant effect on public employees (Alumni) performance

In this study, the independent variable was in-house training programme measured as induction (IND), Team building (TB), Strategic Leadership (SL), Impact Assessment (IA), Performance Enhancement (PE) and Voluntary Retirement (VR) while Employee performance (EP) was the dependent variable. Results from regression model summary, Table 2 below shows that $R^{2}$ value is 0.577 , which means that $57.7 \%$ of the total variance in employee performance (EP) has been explained. This means that in-house training programmes contribute to the realization of strategic human development goals and plans. 


\begin{tabular}{|c|c|c|c|c|}
\hline \multicolumn{5}{|c|}{ Model Summary } \\
\hline Model & $\mathrm{R}$ & R Square & Adjusted R Square & Std. Error of the Estimate \\
\hline 1 & $.760^{\mathrm{a}}$ & 0.577 & 0.569 & 5.65177 \\
\hline \multicolumn{5}{|c|}{ a. Predictors: (Constant), IND, TB, SL, IA, PE, VR } \\
\hline \multicolumn{4}{|c|}{ Table 2: Regression Model Summary } \\
Source: Survey Data (2021)
\end{tabular}

\begin{tabular}{|c|c|c|c|c|c|c|}
\hline \multicolumn{7}{|c|}{ ANOVA $^{\mathbf{b}}$} \\
\hline \multirow{2}{*}{ Model } & Sum of Squares & df & Mean Square & F & Sig. \\
\hline \multirow{3}{*}{1} & Regression & 4196.48 & 6 & 1049.12 & 32.390 & $.001^{\mathbf{b}}$ \\
\cline { 2 - 6 } & Residual & 3076.78 & 94 & 32.39 & & \\
\cline { 2 - 6 } & Total & 7273.26 & 100 & & & \\
\hline \multicolumn{6}{|c|}{ a. Predictors: (Constant), IND, TB, SL, IA, PE, VR } \\
b. Dependent Variable: EP \\
Tignificant Level at 0.05 (2 Tailed) \\
Source: Survey Data (2021)
\end{tabular}

Table 3 above show the ANOVA result on the impact of in-house training programmes and employee (Alumni) performance. Results revealed that in-service training programmes does have significant affect employee (Alumni) performance $(\mathrm{F}=32.390 ; \mathrm{p}>0.05)$. The result show that the significance value of 0.001 was less than the probability value of 0.05 . This shows significant relationship between in-service training programmes and employee (Alumni) job performance. Therefore, the null hypothesis which stated that in-service training programmes does not enhance employee (Alumni) job performance was rejected and the alternative accepted and concluded that in-service training programmes does significantly affect employee (Alumni) job performance.

\begin{tabular}{|c|c|c|c|c|c|c|}
\hline Model & $\begin{array}{c}\text { Unstandardized } \\
\text { Coefficients }\end{array}$ & $\begin{array}{c}\text { Standardized } \\
\text { Coefficient }\end{array}$ & & & \\
\hline Constructs & $\mathbf{B}$ & $\begin{array}{c}\text { Standard } \\
\text { Error }\end{array}$ & Beta $\quad \boldsymbol{\beta}$ & $\mathbf{t}$ & P-Value & Interpretation \\
\hline (Constant) & 87.84 & 6.386 & & 4.474 & 0.001 & Significant \\
\hline IND & 0.348 & 0.023 & 0.412 & 1.881 & 0.009 & Significant \\
\hline TB & 0.301 & 0.012 & 0.278 & 1.344 & 0.006 & Significant \\
\hline SL & 0.398 & 0.009 & 0.290 & 1.765 & 0.001 & Significant \\
\hline IA & 0.564 & 0.007 & 0.873 & 7.598 & 0.000 & Significant \\
\hline PE & 0.389 & 0.012 & 0.368 & 5.252 & 0.000 & Significant \\
\hline VR & 0.050 & 0.062 & 0.054 & 0.801 & 0.031 & Significant \\
\hline \multicolumn{7}{|c|}{ a. Dependent Variable: EP } \\
\hline
\end{tabular}

Table 4: Regression Coefficient

Significant Level at 0.05 (2 Tailed)

Source: Survey Data (2021)

Results in Table 4 above shows a multiple regression was run to predict employee (Alumni) job performance (dependent variable) from induction (IND), Team building (TB), Strategic Leadership (SL), Impact Assessment (IA), Performance Enhancement (PE) and Voluntary Retirement (VR) as independent variables. The result revealed that the coefficient of the constant term (86.84) was positive. This indicated that positive association existed between dependent variable and independent variables. The coefficients and the $p$-values for in-service training [IND $(0.348, p=0.009)$; TB (0.301, $\mathrm{p}=0.006)$; SL $(0.398, \mathrm{p}=0.001)$; IA (0.564, $\mathrm{p}=0.000)$; PE $(0.389, \mathrm{p}=0.000)$; VR $(0.050, \mathrm{p}=0.031)]$. The results indicated that in-service training programmes had positive effect on employee (Alumni) job performance.

Conclusively, the independent variable (in-house training programmes statistically significantly predicted employee (Alumni) job performance, $F(6,94)=32.390, p<.005, R^{2}=.577$ and all the six variables added, were statistically significantly to the prediction, $p<.05$.

\section{Discussion}

In this dynamic and fast changing world, different factors play significant role in progress and advance of organizations, implying that in service training plays a significant role. Since expectations face growing change, employees need to change their efficiency to be able to meet daily challenges at their work place. The theoretical contribution of the paper is that in-service training programmes stands against rigidness and the result is improvement and advancement in 
the skills base of an employee for enhanced productivity and transformation of organizations within which they operate.

In order to analyse different aspects of the issue, different hypothesis described above are now under discussion

The study findings are in disagreement with Oni et al (2013) and Atif et al (2011) studies that concluded that employees' training had insignificant effect on employees; productivity. The study findings are supported by Chris (2011), Samaneh\&Zoure (2014) and Aroge (2012) studies that found significant relationship between employees' training and employees' performance.

The study findings are supported by Iwuoha (2002) and Ezeani (2013) whose studies concluded that staff development has no significant relationship with employees' productivity. The study findings further disagreed with Atif et al (2011) study that found insignificant relationship between employees' training and development and employees' productivity.

The study findings concur with Ahmed and Hanson (2011) study that observed that developing the capacity of public officers, is fundamental to instill self-confidence plus inspire employees into a common idea to realize organizational objectives. The study findings also agree with Espinos (2009) whose study conducted hat the quality of courses, increased skills and expertise are the important factors of participating in in-service training courses.

\section{Conclusions}

The study established that personnel development is an important activity in organizational management which reflects the innovativeness of employees in such organizations and also indicates new way of working principles/relations and enhancing employees' productivity for optimal job performance. In-service training programmes and employee (Alumni)'s performance should be important issues in organizational management, as all goal driven organization, always strive to employ the services of skilled and capable employees for better productivity. This is made possible through the constant and frequent in-service training and development programmes being offered by the CSCU. Therefore, In-service training programmes offered by CSCU provide public employees (Alumni) with the opportunities to improve their career opportunities and enhances them to get in better positions in the organization and in doing so, organizations efficiency would be increased.

\section{Recommendations}

The study established that the Uganda government through her Ministry of Public Service-Civil Service College Uganda undertakes training needs assessment for different cadres (public employees) before administering in-service training. Since needs assessment is a dynamic and continuous process, the government should promote the deployment of modern technologies such as online learning in order to enhance timely information on training needs for decision making purposes.

Results indicate that in-service training opportunities granted empowerment to public employees in decision making and improving organisation productivity. These trainings equipped public employees for higher occupational abilities. Holding in-service training programmes lead to individuals' success and probably to institutional goal achievement.

Based on the findings it was recommended among others that CSCU should continue to design proper and functioning in-service training programmes for public employees to enhance their performance. Institutional managements should also ensure employee training are conducted frequently to ensure they cope with changing work environments and allow employees some degree of autonomy in the use of their ideas to ensure they contribute positively to organization effectiveness and performance.

\section{References}

i. Ahmed, A., \& Hanson, K. T. (2011). Leadership, capacity building and sustainable development in contemporary Africa. World Journal of Entrepreneurship, Management and Sustainable Development, 7(2/3/4), 101-111.

ii. Appiah B.A, (2010). The Impact of Training on Employee Performance: A Case Study of HFC Bank (Ghana) Ltd.

iii. Aroge, S. T. (2012): Employee's Training and Development for Optimum Productivity: The Role of Industrial Training Fund (ITF), Nigeria, Developing Country Studies. 2(4): 50-59.

iv. Atif, H., Ijaz, L. P., Abdul, K. G. \& Nadeem, G. (2011). Employee Retention Relationship to Training and Development from Compensation Perspective. Journal of personnel management. 5(2): 24-41.

v. Ebru. M. K (2015): A General Investigation of the In-Service Training of English Language Teachers at Elementary Schools in Turkey. International Electronic Journal of Elementary Education, 2016, 8(3), 455-466

vi. Emojong, J. (2004). In-service training programs and their effects on the performance of staff at the Uganda Revenue Authority. Unpublished Masters Dissertation, Makerere University

vii. Espinos, M., (2009). Continuing Library Education Needs in Spanish. IFLA (Barcelona, 22-28 August 1993). Available at: www.fla.queenslibrary.Org/IV/ifla59/59dbd.txt. Educational Technology Society. 52 105-119

viii. ETF-Cedefop-ILO (2016): Carrying out tracer studies - Guide to anticipating and matching skills and jobs Vol. 6, available at: http://www.etf.europa.eu/web.nsf/pages/Vol._6_Tracer_studies

ix. Ezeani, N. S. (2013): Implications of Training and Development Programmes on Accountants Productivity in Selected Business Organizations in Onitsha, Anambra State, Nigeria, International journal of Asian Social Science. 3(1):266-281.

x. Ezigbo C.A., (2003): Advance management Theory, Enugu, Immaculate Publication Limited

xi. Grinyer, A., \&Singleton, V. (2000): Sickness absence as risk-taking behaviour: A study of organizational and cultural factors in the public sector. Health, Risk \& Society,2, 7-21. 
xii. Holbrook A, Krosnick J and Pfent A., (2007): The Causes and Consequences of Response Rates in Surveys by the News Media and Government Contractor Survey Research Firms. DOI: 10.1002/9780470173404.ch23. In book: Advances in Telephone Survey Methodology (pp.499-528)

xiii. Iwuoha, U. (2002): Productivity and Capacity Building. Proceedings of the 9th Annual Conference of the Zonal Research Units, Gateway Hotel, Abeokuta, 12-16 June

xiv. Joppe, M. (2000): The Research Process.Accessed at: http://www.ryerson.ca/ mjoppe/rp.htm

xv. Lahsaeezadeh, M. (2005): In-service training dimensions: concepts, Andishe Journal, Vol. 3, No. 16, p.24.

xvi. Mirsepasi, N. (2010): Productivity and Productivity Evaluation Principles, School Publication, p.89, Tehran, Iran.

xvii. Ministry of Public Service (MoPS) Ministerial Policy Statement (2020)

xviii. Oni, P., Mukaila, D. R. \& Musa, T. R. (2013): Impact of Training and Management Development in the Nigerian Banking Industry. International Journal of Management. 12 (3): 241-252.

xix. Reyans, M. J. (1963): Personnel management (5th ed.). Homewood, IL: Richard D. Irwin

xx. Samaneh, H. \&Zoure, E. (2014): Evaluation of In-service Training to Increase Employees' Productivity of Isfahan University Technology (IUT). Strategic Management Journal. 12 (2):257-273.

xxi. Schaefer D and Dillman D., (1998): Development of a Standard E-Mail Methodology: Results of an Experiment. DOI: $10.1086 / 297851$

xxii. Unwin, L. (2003): Being Responsive: Colleges, communities and 'stakeholders' in Cosser, I., Macgrath, S., Badroodien, A. and Maja B. (editors). HSRC Publishers, Capetown

xxiii. Visser P. S, Krosnick J. A, Marquette J, Curtin M., (1996): Mail surveys for election fore-casting? An evaluation of the Columbus Dispatch poll. Public Opin. Q.60:181 ñ227

xxiv. William, J, Rothwell H and Kazanas C., (2004): Improving On-the-Job Training: How to Establish and Operate a Comprehensive 0JT Program

xxv. Yamane, T., (1967): Statistics, An Introductory Analysis, 2nd Ed., New York: Harper and Row 